\title{
Evaluation of computed tomography in vascular lesions of the vertebrobasilar territory
}

\author{
D P E KINGSLEY, E W RADUE AND E P G H DU BOULAY \\ From the Lysholm Radiological Department, The Nation Hospital for Nervous Diseases, London
}

SUMMARY Forty-nine patients with clinical features of vascular disease in the vertebrobasilar territory were examined to evaluate the diagnostic performance of computed tomography. It provided useful information in the diagnosis of acute vascular lesions in patients in whom a definite episode had occurred not longer than 2 weeks before computed tomography was undertaken. It was of value in both haemorrhagic and thromboembolic groups but in many patients angiography was required to make a substantive diagnosis. It was of less value in patients with vague and ill defined symptoms and of no value in transient ischaemia.

In the cerebrum vascular abnormalities such as infarcts $^{12}$ haemorrhages ${ }^{3-6}$ and aneurysms ${ }^{7}$ are usually well demonstrated by computed tomography (CT) although considerable disability may occasionally be accompanied by a normal computed tomogram. On the other hand vascular disease of the vertebrobasilar territory is frequently difficult to assess not only because of the vague symptomatology but because the posterior fossa remains a difficult area to visualise, small lesions being easily missed. In addition longstanding vascular disease may result in a scan demonstrating only cerebellar and brain stem atrophy. ${ }^{8}$ Since the clinical diagnosis of a vascular lesion involving the vertebrobasilar territory is not infrequently made, we considered it would be of value to assess the accuracy of computed tomography in making a definitive diagnosis, in detecting other changes which although not directly related were possibly of a vascular nature and in addition, in assessing the need for other radiological investigations to confirm the clinical diagnosis.

\section{Methods}

Details of patients with a clinical diagnosis of vascular disease related to the vertebrobasilar territory obtained from the computer register at the National Hospital for Nervous Diseases,

Address for reprint requests: Dr DPE Kingsley, The London Hospital, Whitechapel, London E1 1 BB.

Accepted 24 September 1979 between early 1974 and mid 1976. There were 49 patients, 29 males and 20 females. The notes, CT scans and angiograms of all patients were examined to assess the correlations between clinical diagnosis, $\mathrm{CT}$ and other radiological findings. In many cases a definitive diagnosis was never completely established.

The length of time between onset of symptoms and CT was divided into four groups: -

1 One to two days (ten patients)

2 Three to six days (five patients)

3 One to two weeks (eight patients)

4 Greater than four weeks (26 patients)

\section{Results}

Group One: (ten patients) Eight of the CT scans were abnormal and two were normal. Both patients with normal CT scans had a definite history of a brain stem vascular episode of gradual onset with a previous history of purely transient ischaemic attacks in the vertebrobasilar territory consisting of vertigo, nausea and vomiting, ataxia and long tract signs. In both patients the clinical features of the most recent attack were also transient although one lasted 24 hours. Angiography was not performed on either patient but air encephalography demonstrated cortical atrophy in one.

Of the eight patients with abnormal CT there was precise correlation between $C T$ and the clinical features in four. In one patient, scanned two days after a subarachnoid haemorrhage, the 
basilar tip aneurysm responsible was demonstrated both before and after intravenous contrast enhancement. There was no blood in the basal cisterns. In a second patient with a basilar tip aneurysm subarachnoid haemorrhage was demonstrated on computed tomography, but the aneurysm was only diagnosed at vertebral angiography. A third patient had a history of a stroke in evolution over two days and CT showed low attenuation in the cerebellum and brain stem with enhancement after the injection of contrast. In a fourth case, with a sudden onset of symptoms, the appearances (a low attenuation area) were those of an infarct.

In the other four patients correlation between the clinical course and the CT scan was poor. Atrophy of the cerebellum and cerebral cortex was present in two, one of whom died (further reference will be made to this patient later). There was atrophy of the cerebral cortex alone in one and in the fourth patient, with quadriplegia and expressive dysphasia ("locked-in syndrome"), computed tomography showed slight dilatation of the lateral ventricles without abnormality in the posterior fossa. This patient was only scanned once and the ventricular dilatation may have represented early hydrocephalus perhaps due to a cerebellar infarct that had not been shown by CT. Two patients in this group died; one following a subarachnoid haemorrhage and the other, (previously referred to) after extensive infarction in the right middle cerebral and vertebrobasilar territory revealed only at post mortem. The scan showing atrophy only had been undertaken within 12 hours of the onset of the clinical symptoms, but 36 hours before death.

In the eight cases with abnormal CT, five showed clinical features of sudden onset and in seven some of the neurological disability was permanent.

Group Two: (five patients) All five patients in this group had abnormal computed tomograms. High density lesions consistent with haemorrhage were shown in the cerebellum in three, all with symptoms of sudden onset, blood being also present in the brainstem in one of them and subsequently confirmed by angiography. Contrast was not given to a second patient later shown by angiography to have an angioma. The third patient, a child of seven was admitted comatose and died shortly afterwards. Necropsy was not undertaken.

Neither of the other two patients had CT changes in the posterior fossa. One was shown to have a small basilar tip aneurysm by angiography not visible on an unenhanced scan. The basal cisterns were normal, the subarachnoid haemorrhage having occurred six days before scanning. The other patient, with a progressive five day history of vertebrobasilar insufficiency (VBI) showed only cortical atrophy on the scan which was undertaken two days before his sudden deterioration, terminal collapse and subsequent death. A post mortem examination revealed basilar artery occlusion.

Group Three: (eight patients) All patients were scanned between seven and 14 days after the episode. There were seven abnormal scans. Three had high density lesions in the posterior fossa. The only patient in this group with a sudden onset of symptoms suffered a brain stem haemorrhage diagnosed clinically and on CT. One had a stuttering but progressive history of dysarthria, ataxia and diplopia over six days; CT demonstrated a basilar aneurysm without evidence of haemorrhage. The third demonstrated an enhancing mass in the left cerebellar hemisphere diagnosed at angiography as an angioma.

Two patients had low attenuation lesions in the cerebellum. One presented with a history suggestive of a cerebellar and brain stem infarct while the other, with symptoms pointing to supratentorial as well as infratentorial vascular disease, showed cortical atrophy as well. In the remaining two patients the abnormal scans demonstrated cerebral atrophy only. Both these patients had long histories, one of dementia and Parkinson's disease and the other of a previous head injury, but are included here because they presented with more acute episodes of ataxia and vertigo. The last patient in this group had a normal scan after three transient ischaemic episodes related to the posterior fossa over a two week period.

Group Four: (26 patients) Except for three patients scanned at four, five and six weeks after the ictus, all scans were undertaken at least eight weeks after the onset of the symptoms. Sixteen patients had abnormal and 10 normal scans. The patients with abnormal scans will be described first. Two had high density lesions in the prepontine cistern; angiography confirmed a basilar artery aneurysm in one and a calcified basilar artery occlusion in the other. Both cases had long histories, the patient with a basilar aneurysm having had transient ischaemic symptoms since a head injury six weeks previously, while the patient with basilar artery occlusion had had an acute episode without progression one year previously. Two patients had low attenuation lesions 
consistent with infarcts in the vertebrobasilar territory. Two patients had atrophy of the cerebellar hemispheres. Seven patients had cerebral atrophy, one had a cerebral cortical infarct and two appeared to have hydrocephalus. Five of these patients with cerebral disease had ischaemic symptoms, three being transient. The other five had vague symptoms. Most of the ten patients with normal CT scans (cases 40 to 49) presented with a history of transient ischaemia. None of these had other investigations and their diagnoses remain unconfirmed.

\section{Discussion}

The purpose of this paper has been to assess retrcspectively the diagnostic performance of computed tomography in those with a confirmed or presumed diagnosis of a vascular lesion in the posterior fossa. Although a number of patients were included in whom the clinical diagnosis was equivocal and whose scans were normal the majority fell into two main groups, those with haemorrhage and those with thromboembolic disease. They are discussed together because in practice the presenting features are often similar.

Initial assessment of this diverse group of patients separated them almost equally into two groups, those (23 patients) in whom the scan was undertaken early, between one and 14 days after the ictus and those ( 26 patients) where the scan was undertaken more than 1 month after the onset of the symptoms.

We divided the patients scanned within the first two weeks into three subgroups since we thought it possible that thromboembolic lesions scanned within two days of the ictus might not yet be demonstrated on CT while in those patients with subarachnoid haemorrhage a transiently abnormal scan might already have returned to normal by the time the scan was undertaken. No difference was found, however, between these three subgroups. Twenty of these scans were abnormal and in two of the three normal scans, the symptoms were of transient ischaemia.

In all groups there were patients with basilar aneurysms, haemorrhages and infarcts in the vertebrobasilar territory. as well as five patients with changes outside the posterior fossa. Of these one probably was developing hydrocephalus due to a brain stem haemorrhage, while another had an evolving but incomplete stroke at the time of his scan which was normal.

There was agreement between the clinical and CT diagnosis in 14 patients, all of whom had either posterior fossa haemorrhages or low density infarcts. The primary pathology, either angioma or aneurysm, required confirmation by angiography. In the group of patients scanned late in their disease there was considerably less correlation between the clinical features and CT. Apart from two basilar aneurysms, evidence of old infarcts in the vertebrobasilar territory in two and cerebellar atrophy in a further two, CT only gave nonspecific information.

A further evaluation of the diagnostic limitations of CT scanning was undertaken in the thromboembolic group of patients alone. If those whose clinical features were strongly suggestive of an infarct or transient ischaemia are considered (table 5 ) only six out of $14(43 \%)$ clinically diagnosed infarcts or strokes in evolution and none of 17 clinically diagnosed transient ischaemic attacks demonstrated CT changes consistent with infarction in the vertebrobasilar territory. Three patients with normal scans had strokes in evolution and it is possible that a subsequent scan would have revealed an infarct in these patients. Cerebellar atrophy possibly due to previous vertebrobasilar disease was observed in one patient with a clinical infarct and one with transient ischaemia, both of whom were in group 4. There is no evidence that computed tomography provided any positive information in patients with transient ischaemic attacks alone.

Computed tomography therefore provides useful information in the diagnosis of the acute vascular lesions of the posterior fossa in those in whom a definite episode has occurred not longer than two weeks before computed tomography is undertaken. It is of value in both the haemorrhagic and thromboembolic groups, but in many of these angiography is required to make a definite diagnosis. Computed tomography is of less value in the group of patients with vague and ill defined symptoms, suggestive of vertebrobasilar disease, but without evidence of an acute episode and it is of no diagnostic value in transient ischaemia.

We wish to thank Miss Wendy Pidgeon for her secretarial help. 
Table 1 Group 1-Time between ictus and CT scan 1 - 2 days

\begin{tabular}{|c|c|c|c|c|c|c|}
\hline Case no. & Onset & Clinical diagnosis & Plain CT findings & Enhanced $C T$ findings & $\begin{array}{l}\text { Angiogram } \\
\text { diagnosis }\end{array}$ & Final diagnosis \\
\hline 1 & Sudden & Basilar aneurysm & $\begin{array}{l}\text { Pontine \& 4th ventricular } \\
\text { haemorrhage }\end{array}$ & $\begin{array}{l}\text { Enhancement of } \\
\text { aneurysm }\end{array}$ & Aneurysm & Basilar aneurysm \\
\hline 2 & Sudden & $\begin{array}{l}\text { SAH } \\
\text { Basilar aneurysm }\end{array}$ & SAH & No enhancement & Aneurysm & Basilar aneurysm \\
\hline 3 & Sudden & Brainstem infarct & $\begin{array}{l}\text { Low attenuation in } \\
\text { brainstem and cerebellum }\end{array}$ & No enhancement & Not done & Brainstem infarct \\
\hline 4 & Gradual & $\begin{array}{l}\text { Posterior fossa } \\
\text { infarct }\end{array}$ & $\begin{array}{l}\text { Low attenuation in } \\
\text { cerebellum }\end{array}$ & Enhancement & Not done & Cerebellar infarct \\
\hline 5 & Sudden & $\begin{array}{l}\text { Posterior fossa } \\
\text { infarct }\end{array}$ & $\begin{array}{l}\text { Cerebellar and cerebral } \\
\text { atrophy }\end{array}$ & Contrast not given & Not done & $\begin{array}{l}\text { Multiple infarcts } \\
\text { (death) }\end{array}$ \\
\hline 6 & Gradual & ? Embolic & $\begin{array}{l}\text { Cerebellar and cerebral } \\
\text { atrophy }\end{array}$ & Contrast not given & $\begin{array}{l}\text { Vertebral artery } \\
\text { stenosis }\end{array}$ & Probably ischaemic \\
\hline $\begin{array}{r}7 \\
8 \\
9 \\
10\end{array}$ & $\begin{array}{l}\text { Gradual } \\
\text { Sudden } \\
\text { Gradual } \\
\text { Gradual }\end{array}$ & $\begin{array}{l}\text { ? Ischaemia } \\
\text { Brainstem infarct } \\
\text { TIA } \\
\text { TIA }\end{array}$ & $\begin{array}{l}\text { Cerebral atrophy } \\
\text { ? Early hydrocephalus } \\
\text { Normal } \\
\text { Normal }\end{array}$ & $\begin{array}{l}\text { Contrast not given } \\
\text { Contrast not given } \\
\text { Contrast not given } \\
\text { Contrast not given }\end{array}$ & $\begin{array}{l}\text { Not done } \\
\text { Not done } \\
\text { Not done } \\
\text { Not done }\end{array}$ & $\begin{array}{l}\text { Not confirmed } \\
\text { Brainstem infarct } \\
\text { TIA } \\
\text { TIA }\end{array}$ \\
\hline
\end{tabular}

Iable 2 (ircup 2-Time between ictus and C'T scan 3-6 days

\begin{tabular}{|c|c|c|c|c|c|c|}
\hline Case no. & Onset & Clinical diagnosis & Plain CT findings & Enhanced CT findings & Angiogram & Final diagnosis \\
\hline 11 & $\begin{array}{l}\text { Gradual } \\
\text { over } \\
4 \text { days }\end{array}$ & $\begin{array}{l}\text { Cerebellar } \\
\text { haemorrhage }\end{array}$ & $\begin{array}{l}\text { Cerebellar and Brainstem } \\
\text { haemorrhage }\end{array}$ & No enhancement & $\begin{array}{l}\text { Angioma } \\
\text { left cerebellar } \\
\text { haemorrhage }\end{array}$ & $\begin{array}{l}\text { Angioma } \\
\text { haemorrhage }\end{array}$ \\
\hline 12 & Sudden & $\begin{array}{l}\text { Posterior fossa } \\
\text { haemorrhage }\end{array}$ & $\begin{array}{l}\text { Cerebellar and brainstem } \\
\text { haemorrhage }\end{array}$ & Contrast not given & Not done & $\begin{array}{l}\text { Brainstem } \\
\text { haemorrhage } \\
\text { (death) }\end{array}$ \\
\hline 13 & Sudden & $\begin{array}{l}\text { Cerebellar } \\
\text { haemorrhage }\end{array}$ & $\begin{array}{l}\text { Subarachnoid and } \\
\text { cerebellar haemorrhage }\end{array}$ & Contrast not given & Angioma of vermis & $\begin{array}{l}\text { Angioma } \\
\text { haemorrhage }\end{array}$ \\
\hline 14 & Sudden & $\begin{array}{c}\text { Subarachnoid } \\
\text { haemorrhage }\end{array}$ & $\begin{array}{l}\text { 4th ventricle displaced } \\
\text { backwards }\end{array}$ & Contrast not given & Basilar aneurysm & Basilar aneurysm \\
\hline 15 & Gradual & Stroke in evolution & Cerebral atrophy & Contrast not given & Not done & Infarct \\
\hline
\end{tabular}

Table 3 Group 3-Time between ictus and CT scan 7-14 days

\begin{tabular}{|c|c|c|c|c|c|c|}
\hline Case no. & Onset & Clinical diagnosis & Plain CT findings & Enhanced $C T$ findings & Angiogram & Final diagnosis \\
\hline 16 & Sudden & $\begin{array}{l}\text { Pontine } \\
\text { haemorrhage }\end{array}$ & Pontine haemorrhage & Contrast not given & Not done & $\begin{array}{l}\text { Pontine } \\
\text { haemorrhage }\end{array}$ \\
\hline 17 & Gradual & $\begin{array}{l}\text { Brainstem lesion } \\
\text { type }\end{array}$ & High density mass & $\begin{array}{l}\text { Enhanced } \\
\quad \text { (Vascular tumour) }\end{array}$ & Angioma & $\begin{array}{l}\text { Pontine } \\
\text { angiomatous } \\
\text { malformation }\end{array}$ \\
\hline 18 & Gradual & Brainstem infarct & $\begin{array}{l}\text { High density lesion in } \\
\text { brainstem }\end{array}$ & Enhanced & Aneurysm & Basilar aneurysm \\
\hline 20 & Gradual & $\begin{array}{l}\text { Cerebellar and } \\
\text { brainstem infarct }\end{array}$ & Cerebellar low attenuation & Contrast not given & Not done & Cerebellar infarct \\
\hline 21 & Gradual & $\begin{array}{l}\text { ?Ischaemia, } \\
\text { Parkinsonism }\end{array}$ & Cerebral atrophy & Contrast not given & Not done & Presumed TIA \\
\hline $\begin{array}{l}22 \\
23\end{array}$ & $\begin{array}{l}\text { Gradual } \\
\text { Gradual }\end{array}$ & $\begin{array}{l}\text { ?Ischaemia, trauma } \\
\text { Equivocal }\end{array}$ & $\begin{array}{l}\text { Cerebral atrophy } \\
\text { Normal }\end{array}$ & $\begin{array}{l}\text { Contrast not given } \\
\text { Contrast not given }\end{array}$ & $\begin{array}{l}\text { Not done } \\
\text { Not done }\end{array}$ & $\begin{array}{l}\text { Presumed TIA } \\
\text { Not diagnosed }\end{array}$ \\
\hline
\end{tabular}


Table 4 (iroup 4-Time between ictus and scan-greater than one month (only patients with abnormal scans included)

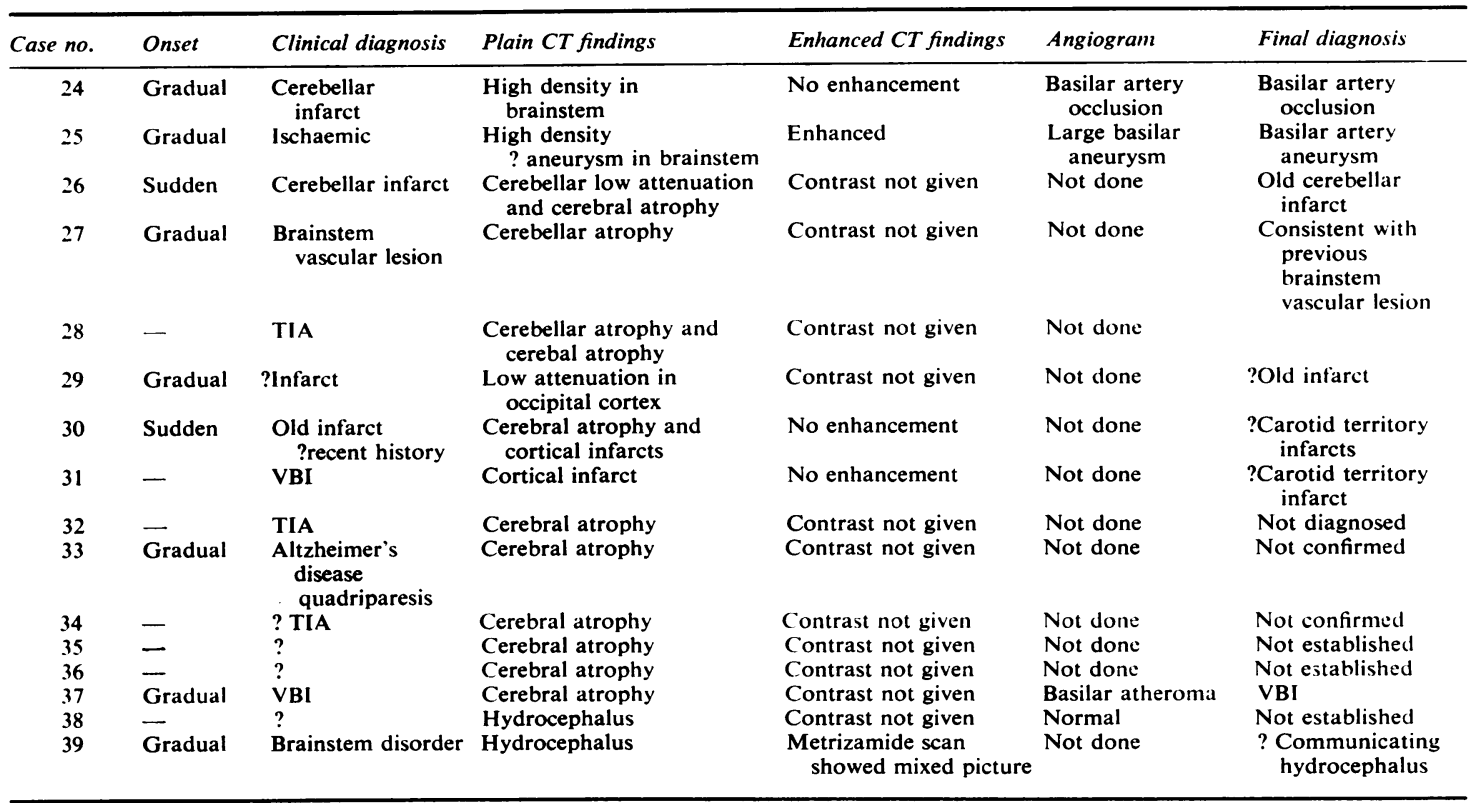

Table 5

\begin{tabular}{llcc}
\hline & & Number & CT Infarct \\
\hline Group 1 & Clinical infarct & 3 & 2 \\
& $\begin{array}{llc}\text { Clinical ischaemia } \\
\text { Stroke in evolution }\end{array}$ & 2 & - \\
Group 2 & $\begin{array}{l}\text { Clinical infarct } \\
\text { Clinical ischaemia }\end{array}$ & -2 & - \\
& Stroke in evolution & 1 & - \\
Group 3 & Clinical infarct & 2 & 2 \\
& Clinical ischaemia & - & - \\
\multirow{2}{*}{ Group 4 } & Stroke in evolution & 1 & - \\
& Clinical infarct & 6 & 2 \\
& Clinical ischaemia & 12 & - \\
& Stroke in evolution & - & - \\
\hline
\end{tabular}

\section{References}

1 Davis KR, Taveras JM, New PFJ, Schnur JA, Roberson GH. Cerebral infarction diagnosis by computerised tomography: analysis and evaluation of findings. $A J R$ 1975; 124:643-60.

2 Norton GA, Kishore PRS, Lin J. CT Contrast enhancement in cerebral infarction. $A J R$ 1978; 131:881-6.

3 Liliequist B, Lundquist $M$, Valdimarsson $E$. Computed tomography and subarachnoid haemorrhage. Neuroradiology 1977; 14:21-6.

4 Kwak S, Inou S, Nagashuna T, Sano K. Classification of intracerebral haemorrhage by means of computed tomography. Neuroradiology 1978; 16:159-61.

5 McCallum JE, Lodolche D, Boehnke M. CT Scan in intraventricular haemorrhage. Correlation of clinical findings with computerised tomographic scans of the brain. Neurosurgery 1978; 3:22-5.

6 Kendall BE, Radue EW. Computed tomography in spontaneous intracerebral haemorrhage. $\mathrm{Br}$ J Radiol 1978; 51:563-73.

7 Pressman BD, Gilbert GE, Davis DO. Computerised transverse tomography of vascular lesions of the brain. Part II Aneurysms. AJR 1975; 124:215-19.

8 Allen JH, Martin JT, Mclain LW. Computed tomography in cerebellar atrophic processes. Radiology 1979; 130:379-82. 